\title{
EFFECT OF TRACE ELEMENT SUPPLEMENTATION TO SUCKLING BUFFALO CALVES
}

\author{
M.A.A. Abd El-Hady ${ }^{1}$, S.A. El-Ayouty ${ }^{2}$ and A.E. Khinizy ${ }^{1}$ \\ 1- Animal Production Research Institute, Agriculture Research Center, Dokki, \\ Giza, Egypt, 2- Department of Animal Production, Faculty of Agriculture, \\ University of Mansoura, Egypt
}

\section{SUMMARY}

A study was conducted to evaluate supplementation of buffalo calves with trace elements up to weaning on performance, blood metabolites and trace element concentrations in blood and tissues. Twenty buffalo calves at the age of 7 days with an average body weight ( $B W)$ of $37.8 \mathrm{~kg}$ were assigned into two groups: 1) Control (C) received no supplement; 2) Trace elements (TE) supplemented group. The trace elements mixture supplied $100 \mathrm{ppm} \mathrm{Fe;} 10 \mathrm{ppm} \mathrm{Cu;} 40 \mathrm{ppm} \mathrm{Zn;} 40 \mathrm{ppm} \mathrm{Mn} \mathrm{(as}$ sulfate compounds); $0.32 \mathrm{ppm}$ Se (as sodium selenite) and $0.5 \mathrm{ppm} \mathrm{I} \mathrm{(as} \mathrm{potassium}$ iodide). Calves were fed on buffalo milk at the rate of $10 \%$ of birth weight from $1^{\text {st }}-4$ weeks of age and then was reduced to $7.5 \%$ from $5^{\text {th }}-8$ weeks, thereafter it was reduced to $5 \%$ from $9^{\text {th }}$ to weaning at 15 weeks. Calf starter and berseem hay were available to animals ad libitum from $2^{\text {nd }}$ week until weaning.

Average daily gains were 0.40 and $0.42 \mathrm{~kg}$ for $C$ and TE groups, respectively without significant difference. However, the final daily gain was higher in TE than $C$ group (0.94 vs. $0.67 \mathrm{~kg} / \mathrm{d})$. Serum glucose in TE was greater $(P<0.05)$ than $C$ group (100.0 vs. $90.2 \mathrm{mg} / \mathrm{dl})$. Serum albumin was lower and globulin higher in TE as compared to $C$ calves $(P<0.10$ and $P<0.05$, respectively). Activity of alkaline phosphatase was higher $(P<0.05)$ in TE than $C$ group, whereas activities of either AST or ALT were not altered. Trace elements supplementation did not affect hemoglobin $(\mathrm{Hb})$, packed cell volume (PCV), mean corpuscular volume $(\mathrm{MCV})$ and mean corpuscular hemoglobin (MCH and MCHC). Red blood cell counts (RBC), white blood cell counts (WBC) and their fractions were not influenced by TE supplementation.

Serum $C u$ was higher $(P<0.05)$ in TE than $C$, but serum $M n$ and Fe tended to decrease. In general, tissue contents of $\mathrm{Cu}, \mathrm{Zn}, \mathrm{Mn}$ and Fe tended to increase in TE group with significance only for liver Cu, spleen $\mathrm{Zn}$ and lung Fe. Hair TE content did not differ between groups. It can be concluded that TE supplementation to suckling buffalo calves had no added value growth rate, blood hematology or metabolites, whereas, $\mathrm{Cu}$ and $\mathrm{Zn}$ status was improved, as well as the immune status of calves.

\section{Keywords: Trace element, supplementation, buffalo calves}

\section{INTRODUCTION}

During pregnancy, trace elements deficiency adversely affects development of the fetus, health and survival of neonates. Among the most limiting trace elements are copper $(\mathrm{Cu})$, zinc $(\mathrm{Zn})$, selenium $(\mathrm{Se})$, and manganese $(\mathrm{Mn})$. Postnatal mortality and Issued by The Egyptian Society of Animal Production 
low birth weights of calves are attributed to $\mathrm{Cu}$ deficiency in beef breeds (Michel, 1976). Anemic calves have higher rates of mortality due to failure of maintaining body temperature (Adams et al., 1993). Zinc deficiency in pregnant ewes decreased body weight of born lambs and reduced $\mathrm{Zn}$ stores in the body (Masters and Moir, 1983).

Milk contents of trace minerals vary widely (Gustafson, 2000 and Hermansen et al., 2005). Milk is deficient in iron, manganese and copper, therefore milk contents from these elements are faraway from covering requirements (NRC, 2001). The contents of $\mathrm{Zn}$, Se and I in milk are not ample and deficiency may appear on suckling calves. The problem of trace element nutrition of suckling calves appears in veal calves fed solely on milk for extended periods. Methods tried to improve trace element nutrition of calves include either supplementation to dams pre- and postpartum or providing calves with the required element(s).

Bremner and Dalgarno (1973) supplied milk- fed calves with up to $100 \mathrm{ppm}$ iron. They observed improvements in weight gain, raised hemoglobin $(\mathrm{Hb})$, packed cell volume (PCV) and plasma Fe levels as the levels of Fe increased. Also, Kume and Tanabe (1994 and 1996) found improvements in Fe status of suckling calves by $\mathrm{Fe}$ supplementation. Plasma $\mathrm{Mn}$ and glucose was not affected by $\mathrm{Mn}$ supplementation to growing and finishing steers (Legleiter et al., 2005).

Selenium supplementation to dams prenatally proved to be efficacious in alleviating deficiency symptoms in calves and enriching milk (Gunter et al., 2003 and Abd El-Hady et al., 2005). Administration of $100 \mathrm{mg} \mathrm{Cu}$ to deficient cows during late pregnancy increased plasma $\mathrm{Cu}$ concentration in calves (Suttle et al., 1980); although Muehlenbein et al. (2001) found that $\mathrm{Cu}$ supplements (200 $\mathrm{mg}$ as $\mathrm{CuSO}_{4}$ or $100 \mathrm{mg}$ as organic $\mathrm{Cu}$ ) to beef cows fed diets low in $\mathrm{Cu}$ pre and postpartum did not improve $\mathrm{Cu}$ in serum, liver or health and growth of the calves. Abd El-Hady et al. (2006) supplied pregnant buffaloes for 60 days prepartum with $50 \mathrm{ppm} \mathrm{Zn}$ as $\mathrm{ZnSO}_{4}, \mathrm{Zn}$ methionine or both. They observed improvements in body weight gains (BWG) of calves and in immune status of dams and calves. Mee et al (1995) found that TE supplement $(\mathrm{Cu}, \mathrm{I}, \mathrm{Se}$ and $\mathrm{Co})$ for pregnant cows for 10 weeks prepartum increased TE in blood of cows and calves.

Supplementation of neonatal calves with minerals was performed in several studies. Dietary supplementation with $\mathrm{Zn}$ over $40 \mathrm{mg} / \mathrm{kg}$ DM and up to $100 \mathrm{mg} / \mathrm{kg}$ DM from inorganic or organic sources had no effect on growth rate from birth up to 90 days (Arrayet et al., 2002). Provision of suckling buffalo calves for the first $69 \mathrm{~d}$ of life with a mixture of major $(\mathrm{Ca}, \mathrm{Mg}, \mathrm{Na}$ and $\mathrm{Cl})$ and minor $(\mathrm{Cu}, \mathrm{Zn}, \mathrm{Mn}, \mathrm{Fe}, \mathrm{I}, \mathrm{Co}$ and $\mathrm{F}$ ) elements tended to improve weight gains but not change $\mathrm{Zn}, \mathrm{Cu}$ concentration in blood serum (Sikka et al., 2002).

The objective of the present study was to evaluate the influence of soluble mixture of trace elements supplementation to suckling buffalo calves on performance and mineral concentrations in blood serum, hair and tissues.

\section{MATERIALS AND METHODS}

\section{1- Animals and management}

This study was conducted on twenty on-week-old buffalo calves at the Buffalo Research Station, Mahallet Mousa, belonging to Animal production Research Institute, Ministry of Agriculture. Calves were left with their dams for the first 3 days 
after birth to get colostrum, thereafter they were separated and kept in individual concrete pens $(140 \mathrm{~cm} \times 120 \mathrm{~cm} \times 106 \mathrm{~cm})$ which were bedded with rice straw. All calves were kept indoors for 3 weeks, after that they were allowed to have exercise from 9:00 am to 2:00 pm daily. Calves were fed whole buffalo milk at 10\% of birth weight (divided into two meals) till the $4^{\text {th }}$ wk of age and then the amount of milk was reduced to $7.5 \%$ tell the $8^{\text {th }} \mathrm{wk}$, thereafter was reduced to $5 \%$ until weaning at 15 wk of age to allow calves consume dry feeds. Calf starter and berssem hay were available to calves ad libitum from the $2^{\text {nd }}$ wk of age in their pens and play yard. Clean drinking water, also, was available to calves twice daily (11:00 am and 2:00 $\mathrm{pm})$. All calves were injected with antiparazitic and vitamin $\mathrm{AD}_{3} \mathrm{E}$. Calves were weighed at the beginning of the experiment and thereafter biweekly until weaning.

\section{2- Experimental design}

The animals were randomly assigned according to body weight and sex of calf to either a control group (C) which was not supplemented by trace elements $(n=10,5$ males and 5 females; body weight $\pm \mathrm{SE}=37.9 \pm 1.5 \mathrm{~kg}$ ) or a supplemented group $(\mathrm{n}=10,5$ males and 5 females; body weight $\pm \mathrm{SE}=37.6 \pm 1.44 \mathrm{~kg})$. The second group was supplemented with a soluble trace element mixture (TE) in drinking milk. This mixture supplied $100 \mathrm{ppm} \mathrm{Fe;} 10 \mathrm{ppm} \mathrm{Cu} ; 40 \mathrm{ppm} \mathrm{Zn;} 40 \mathrm{ppm} \mathrm{Mn} \mathrm{(as} \mathrm{sulfate}$ compounds); $0.32 \mathrm{ppm}$ Se (as sodium selenite) and $0.50 \mathrm{ppm} \mathrm{I} \mathrm{(as} \mathrm{potassium} \mathrm{iodide).}$

\section{3- Blood, hair and tissues collection:}

Blood samples were collected at $2^{\text {nd }}, 4^{\text {th }}, 6^{\text {th }}, 10^{\text {th }}$ and $14^{\text {th }}$ wk of age. Blood samples were collected via jugular venipuncture from each calf using trace mineral evacuated tubes. After a minimum $30 \mathrm{~min}$, samples were centrifuged at 3000 r.p.m for $15 \mathrm{~min}$. to separate blood serum, which was stored frozen at $-20^{\circ} \mathrm{C}$ until determination of trace elements and blood metabolites. Other blood samples were withdrawn into heparinized tubes to determine blood hematology (as RBCs, WBCs, $\mathrm{Hb}, \mathrm{PCV}$, leucocytes and differentiation) using auto blood counter (Cell-Dyn 1800; Abbott Co., USA). Mean corpuscular volume (MCV) and mean corpuscular hemoglobin ( $\mathrm{MCH}$ and $\mathrm{MCHC})$ were calculated as follow: $\mathrm{MCV}=$ mean corpuscular volume (PCV/RBC*10); $\mathrm{MCH}=$ mean corpuscular hemoglobin (hemoglobin/ $\left.\mathrm{RBC}^{*} 10\right) ; \mathrm{MCHC}=$ mean corpuscular hemoglobin concentration (hemoglobin/ $\left.\mathrm{PCV}^{*} 100\right)$.

Blood serum glucose, total protein, albumin, createnine and alkaline phosphatase (Alk-ph) were determined colorimetrically using commercial kits (Spinreact, Spain; Fluitest, Germany; Dialab; ABC Diagnostics, Egypt, respectively) according to the procedures outlined by the manufacture. Also, serum aspartate aminotransferase (AST) and alanine aminotransferase (ALT) activities were determined colorimetrically at $505 \mathrm{~nm}$ according to Reitman and Frankel, (1957). Some physical examination of calves included determination of rectal temperature, diarrhea, anemia, alopecia and white muscle disease (WMD) were specifically evaluated.

Hair samples were collected from the neck and shoulder area of every calf using stainless steel scissors at $6^{\text {th }}$ wk and $15^{\text {th }}$ wk of age and kept frozen in polyethylene bags until preparation for analysis. At the end of the experiment, 3 calves of each group were slaughtered to obtain all carcass data and tissue samples (i.e. liver, spleen, heart, lung, kidney, eye muscle) for mineral analysis. 


\section{4- Hair samples preparation}

Every hair sample was cleaned manually then cut to small parts $(0.5-1.0 \mathrm{~cm})$ and washed 3-4 times by distilled water using small beaker. After that, they were soaked in distilled acetone for $1 \mathrm{hr}$. and washed 3 times with distilled water. Finally, the sample was soaked in acetone for $15 \mathrm{~min}$ and then dried in the oven at $70^{\circ} \mathrm{C}$ for $1 \mathrm{hr}$ and kept in a desiccator (Wasiak et al., 1996).

\section{5- Digestion of samples}

Blood serum samples were treated with $12 \%$ of trichloroacetic acid (TCA) at the ratio 1:3 and shaked by vortex and centrifuged at 3000 r.p.m for $15 \mathrm{~min}$. The clear layer was separated and kept until mineral analysis. Tissues and hair samples were soaked in a digestion mixture containing concentrated $\mathrm{HNO}_{3}, \mathrm{HClO}_{4}$ and $\mathrm{H}_{2} \mathrm{SO}_{4}(70$ : $21: 9 \%$ ) over night. After that, samples were heated on hotplate for about $2 \mathrm{hr}$. until obtaining clear and colorless solution. Samples were transferred quantitatively to 50 $\mathrm{ml}$ volumetric flasks using $0.1 \mathrm{~N} \mathrm{HCl}$ and the volume was completed with distilled water and kept in polyethylene containers until mineral analysis. The trace elements $\mathrm{Fe}, \mathrm{Zn}, \mathrm{Mn}$ and $\mathrm{Cu}$ were determined in digested samples using Atomic Absorption/Flame emission Spectrophotometer (AA-640-13, Shimadzu, Japan). Chemical analysis of feedstuffs (Table 1) was determined according to A.O.A.C. (1990).

Table 1. Chemical composition (\%) and trace element contents (ppm) of the experimental feedstuffs

\begin{tabular}{lccccccccc}
\hline \multirow{2}{*}{ Ration } & \multirow{2}{*}{ DM } & \multicolumn{8}{c}{ On dry matter bases } \\
\cline { 2 - 10 } & & CP & CF & EE & Ash & Cu & Zn & Mn & Fe \\
\hline Calf Starter* & 90.15 & 17.2 & 10.49 & 5.7 & 9.52 & 7.9 & 138.4 & 47.3 & 161.0 \\
Clover Hay & 87.7 & 12.6 & 34.6 & 2.1 & 11.46 & 7.8 & 21.3 & 41.3 & 245.0 \\
\hline
\end{tabular}

*Composition: Yellow corn, soybean meal (44\%), linseed cake, wheat bran, molasses, calcium carbonate and sodium chloride

\section{6- Statistical analysis}

The data of trace element concentrations (of serum and hair), blood metabolites, hematology, growth rate and rectal temperature were analyzed using the general linear models procedure (GLM) of SAS (1996) with a model that included TE (treatment), time of samples and their interaction. Trace element concentrations of tissues were analyzed using proc T-test of SAS. The overall means were compared using Duncan's multiple range test (Duncan, 1955).

\section{RESULTS AND DISCUSSION}

\section{1- Growth rate}

Least square means of initial, final body weight, total gains and daily gains are presented in Table (2). The treated group tended to be higher $(\mathrm{P}>0.05)$ in weaning weight and total and daily gains compared with the untreated group. Mean of daily gain of treated calves in the period from 13 to 15 weeks of age was higher than control (0.94 vs. $0.67 \mathrm{~kg}$; Fig. 1). Body weight increased linearly $(\mathrm{P}<0.01)$ with age (Fig. $1 \& 2$ ). Many studies of trace mineral supplementation revealed non significant 
improvements of growth rate (Zn, Arrayet et al., 2002; Cu, Muehlenbein et al., 2001; Se, El-Ayouty et al., 2003 and Mn, Legleiter et al., 2005). Hemingway et al. (1997) found that growth rates did not differ significantly in dairy weaned calves or suckling beef calves, when they were supplemented with sustained-release boluses containing $\mathrm{TE}(\mathrm{Cu}, \mathrm{Zn}, \mathrm{Mn}, \mathrm{Se}, \mathrm{I}$ and $\mathrm{Co})$ and vitamins (A, $\mathrm{D}_{3}$ and $\left.\mathrm{E}\right)$. They found that mean daily gains were $0.59 \mathrm{~kg}$ and $0.53 \mathrm{~kg}$ for supplemented and unsupplemented dairy calves, respectively. Likewise, non significant improvements in BWG were noted by Sikka et al. (2002) who used mineral mixture and El-Ayouty et al. (1996) who used Se and vitamin E.

Table (2): Body weight and gains of suckling buffalo calves.

\begin{tabular}{|c|c|c|c|c|}
\hline \multicolumn{2}{|l|}{ Items } & Control & Treatment & SE \\
\hline \multicolumn{2}{|c|}{ Body weight (kg): Initial (1 ${ }^{\text {st }}$ wk) } & 37.9 & 37.7 & 2.52 \\
\hline \multicolumn{2}{|c|}{ Final $\left(15^{\text {th }}\right.$ wk $)$} & 76.7 & 78.6 & 2.40 \\
\hline \multirow{2}{*}{\multicolumn{2}{|c|}{$\begin{array}{l}\text { Total Gain (kg) } \\
\text { Daily Gain (kg) }\end{array}$}} & 39.0 & 40.9 & 3.1 \\
\hline & & 0.40 & 0.42 & 0.029 \\
\hline \multirow[t]{2}{*}{ Daily Gain (kg): } & Initial ( $2^{\text {nd }}$ wk) & 0.22 & 0.18 & 0.076 \\
\hline & Final $\left(15^{\text {th }} \mathrm{wk}\right)$ & 0.67 & 0.94 & 0.076 \\
\hline
\end{tabular}

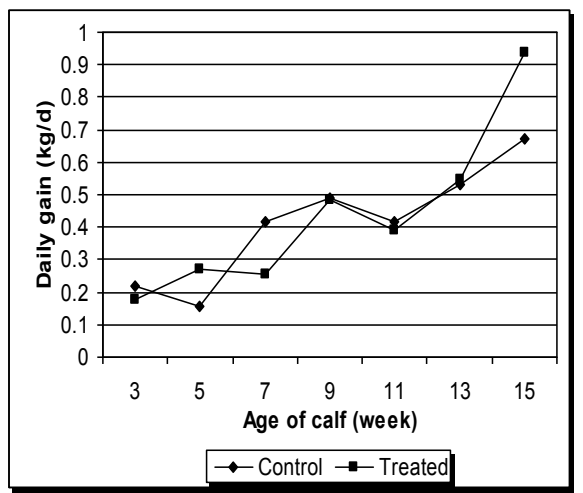

Fig. 1. Daily gain of buffalo calves as affected by $T E$ supplementation at intervals

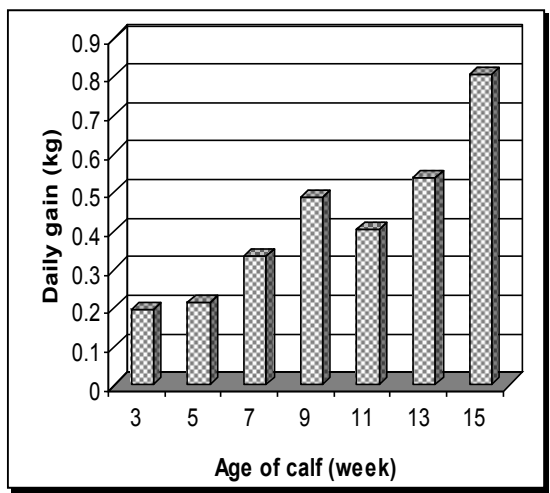

Fig. 2. Daily gain of buffalo calves at consequent age intervals

Abd El-Hady et al. (2006) fund that $\mathrm{Zn}$ supplementation to late pregnancy buffalo cows tended to increase BWG of their calves and the effect was significant with $\mathrm{ZnSO}_{4}+\mathrm{Zn}$ methionine mixture. The BWG values reported herein are similar to the values given by Abd El-Hady et al. (2006) but lower than the values of El-Ayouty et al. (2003).

\section{2- Blood criteria:}

Blood metabolites are shown in Table (3). Trace elements supplementation increased $(\mathrm{P}<0.05)$ plasma glucose levels from 90.2 to $100.0 \mathrm{mg} / \mathrm{dl}$. The increase in glucose concentration was gradual during the course of study. However, Legleiter et al. (2005) found that glucose concentration was not affected by Mn supplementation to growing calves. 
Table 3. Blood Parameters of buffalo calves as affected by trace elements supplementation

\begin{tabular}{lccc}
\hline \multicolumn{1}{c}{ Parameter } & Control & Treatment & SEM \\
\hline Glucose (mg/dl) & 90.2 & $100.0^{* *}$ & 2.87 \\
Total Protein (g/dl) & 5.85 & 6.05 & 0.11 \\
Albumin (g/dl) & 3.16 & $3.00^{*}$ & 0.06 \\
Globulin (g/dl) & 2.64 & $3.06^{* *}$ & 0.12 \\
Alk-ph (U/dl) & 110.6 & $138.7^{* *}$ & 7.83 \\
AST (U/l) & 46.1 & 47.7 & 3.97 \\
ALT (U/l) & 15.8 & 13.1 & 2.22 \\
Createnine (mg/d) & 0.79 & 0.80 & 0.021 \\
\hline
\end{tabular}

$* \mathrm{P}<0.1 ; * * \mathrm{P}<0.05$

Total protein content was 5.85 and $6.05 \mathrm{~g} / \mathrm{dl}$ in $\mathrm{C}$ and TE calves, respectively, without significant differences. Levels of albumin were decreased $(\mathrm{P}<0.1)$ in TE than $\mathrm{C}$ group (3.00 vs. $3.16 \mathrm{~g} / \mathrm{dl})$. Consequently, globulin content was higher $(\mathrm{P}<0.05)$ in TE than C group (3.06 vs. $2.64 \mathrm{~g} / \mathrm{dl}$ ). Therefore, the treated calves had higher immunity compared with untreated calves. Selenium supplementation to buffalo calves did not affect protein albumin or globulin in blood plasma (El-Ayouty et al., 2003). The values of total protein, albumin or globulin found herein are lower than the values reported by El-Ayouty et al. (2003). Kessler et al. (2003) mentioned that serum total protein and albumin were not affected significantly by $\mathrm{Zn}$ supplementation.

The overall mean of Alk-ph activity was elevated in TE than C calves (138.7 vs. 110.6 KU/dl; $\mathrm{P}<0.05)$. The activity of Alk-ph was slightly declined up to $8^{\text {th }}$ wk of age, then increased significantly $(\mathrm{P}<0.01)$ until weaning (Fig. 3 and 4$)$. The result indicates an effective $\mathrm{Zn}$ supplementation (within TE mixture) in improvement of Alk-ph activity. Therefore, $\mathrm{Zn}$ is a constituent of Alk-ph and the activity of the enzyme has been used as a good indicator of $\mathrm{Zn}$ status in the body (Riordan and Vallee, 1976). Our findings are in agreement with those reported by Hatfield et al. (2001) and Kessler et al. (2003). Swinkels et al. (1996) reported that serum Alk-ph activity falls during Zn deficiency. Furthermore, Abd El-Hady et al. (2006) found that $\mathrm{Zn}$ supplementation to late gestation buffaloes improved Alk-ph activity in dams $(\mathrm{P}<0.01)$ and their calves $(\mathrm{P}>0.05)$. On the other side, Wright and Spears (2004) found that $\mathrm{Zn}$ supplementation at $20 \mathrm{mg} / \mathrm{kg}$ DM did not affect plasma Alk-ph activity in Holestein calves. Struharikova et al. (1989) observed that Alk-ph of calves tended to decline with the advancement of age.

Activities of transaminases (AST and ALT) and creatinine concentration were not influenced by TE supplementation. The activity of AST was elevated $(\mathrm{P}<0.01)$ with the advancement of age of calf and arrived to the highest level at $8^{\text {th }}$ week of age (Fig. 5). However, creatinine concentration was declined $(\mathrm{P}<0.01)$ gradually until weaning (Fig. 6). 


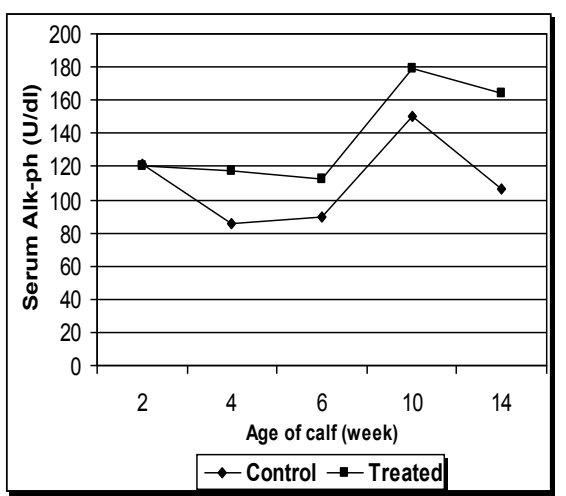

Fig. 3. Serum Alk-ph activity of buffalo calves as affected by $\mathrm{TE}$ supplementation

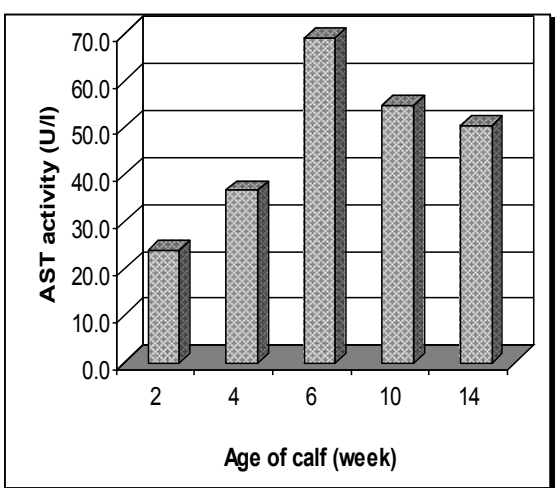

Fig. 5. Serum AST activity of buffalo calves at consequent age intervals

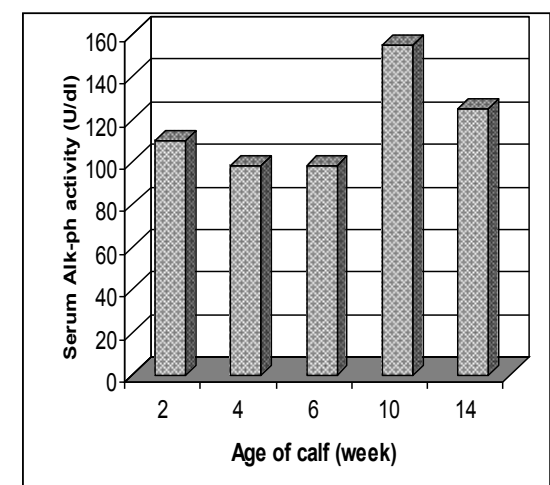

Fig. 4. Serum Alk-ph activity of buffalo calves at consequent age intervals

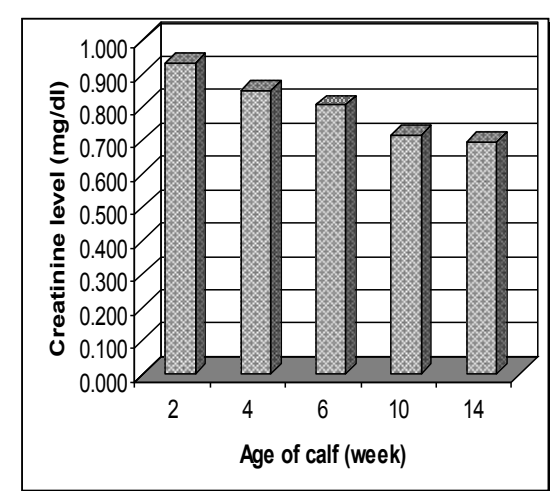

Fig. 6. Serum creatinine levels of buffalo calves at consequent age intervals

\section{3- Blood hematology and cell counts}

Least square means of blood hematology of suckling buffalo calves are shown in Table (4). Trace elements supplementation did not affect hemoglobin (Hb), packed cell volume $(\mathrm{PCV})$, mean corpuscular volume $(\mathrm{MCV})$ and mean corpuscular hemoglobin ( $\mathrm{MCH}$ and $\mathrm{MCHC}$ ). Likewise, white blood cell counts (WBC) and their fractions (lymphpcytes, neutrophil) were not different between TE and C calves. Red blood cell counts (RBC) were not influenced by TE supplementation. Blood Hb, PCV and MCV levels were decreased linearly with the advancement of age (Fig. 7 and 8). The results are in agreement with Roy et al. (1964) who observed that supplementation with $100 \mathrm{ppm}$ Fe to Ayrshire suckling bull calves did not affect $\mathrm{PCV}, \mathrm{Hb}, \mathrm{RBC}, \mathrm{MCV}, \mathrm{MCHC}, \mathrm{WBC}$ and its differentiation. They also found that $\mathrm{Hb}, \mathrm{PCV}$ and MCV declined gradually with the advancement of age. However, Bremner and Dalgarno (1973) found that Fe supplementation to suckling calves 
improved blood $\mathrm{Hb}, \mathrm{PCV}$ and serum Fe but did not affect RBC or WBC. El-Ayouty et al. (2003) found that selenium and/or vitamin E supplementation to suckling buffalo calves did not affect $\mathrm{Hb}$ or PCV. As well as, the results are in agreement with Kessler et al. (2003), who found that organic and inorganic forms of $\mathrm{Zn}$ supplementation to Holestein crossbred bulls did not affect metabolic profile as $\mathrm{Hb}$, $\mathrm{PCV}, \mathrm{RBC}, \mathrm{MCV}, \mathrm{MCH}$ and MCHC.

Table 4. Blood hematology of buffalo calves affected by TE supplementation

\begin{tabular}{|c|c|c|c|c|c|c|c|c|c|}
\hline \multirow{2}{*}{ Items } & \multicolumn{4}{|c|}{ Control } & \multicolumn{4}{|c|}{ Treatment } & \multirow{2}{*}{ SE } \\
\hline & Wk 2 & 4 & 6 & 10 & Wk 2 & 4 & 6 & 10 & \\
\hline WBC $\times 10^{3}$ & 9.8 & 10.8 & 10.1 & 8.6 & 9.1 & 10.1 & 9.8 & 8.7 & 0.92 \\
\hline Lymph\% & 54.1 & 53.1 & 53.2 & 52.2 & 49.4 & 52.0 & 53.5 & 57.8 & 2.57 \\
\hline Neutrophil\% & 25.1 & 26.0 & 28.6 & 27.5 & 29.6 & 25.1 & 26.4 & 25.8 & 2.31 \\
\hline RBC, $10^{6} \times \mu l$ & 6.81 & 6.54 & 5.97 & 6.53 & 6.58 & 6.83 & 6.44 & 6.42 & 0.26 \\
\hline $\mathrm{Hb}, \mathrm{g} / \mathbf{d l}^{\mathrm{a}}$ & 12.4 & 11.6 & 10.4 & 11.1 & 12.2 & 11.8 & 11.5 & 11.5 & 0.48 \\
\hline PCV, \% & 29.7 & 27.4 & 24.7 & 26.4 & 29.1 & 27.9 & 26.3 & 25.6 & 1.22 \\
\hline $\mathrm{MCV}, \mathrm{fl}^{\mathrm{b}}$ & 43.7 & 42.2 & 41.1 & 40.3 & 45.0 & 40.9 & 40.8 & 39.8 & 1.27 \\
\hline MCH, pg/cell & 18.6 & 17.6 & 17.4 & 17.0 & 18.8 & 17.4 & 18.2 & 18.0 & 0.77 \\
\hline МСНС, \% & 42.6 & 41.5 & 42.5 & 42.2 & 42.4 & 41.6 & 44.6 & 45.5 & 1.81 \\
\hline
\end{tabular}

${ }^{\mathrm{a}}$ Age, $\mathrm{P}<0.05 ;{ }^{\mathrm{b}}$ Age, $\mathrm{P}<0.01 ; \mathrm{WBC}=$ white blood cell count; $\mathrm{RBC}=$ red blood cell count; $\mathrm{Hb}=$ hemoglobin; $\mathrm{PCV}=$ packed cell volume; $\mathrm{MCV}=$ mean corpuscular volume $(\mathrm{PCV} / \mathrm{RBC} * 10) ; \mathrm{MCH}=$ mean corpuscular hemoglobin (hemoglobin/ $\mathrm{RBC} * 10) ; \mathrm{MCHC}=$ mean corpuscular hemoglobin concentration (hemoglobin/PCV*100).

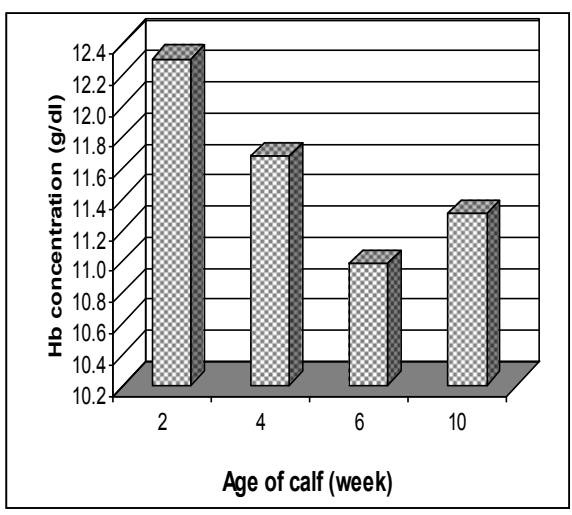

Fig. 7. Blood hemoglobin concentrations of buffalo calves at consequent age intervals

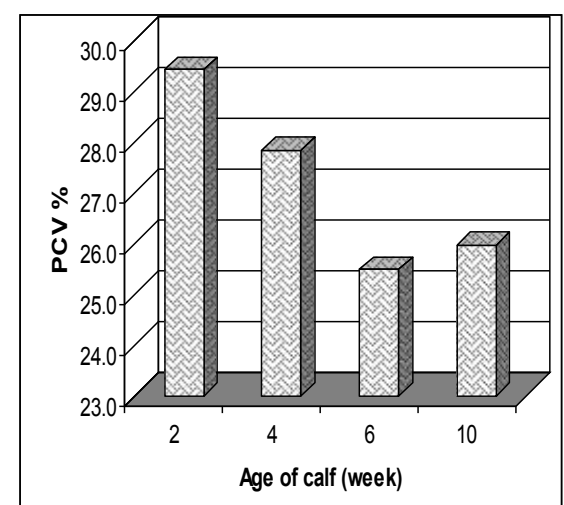

Fig. 8. Blood peaked cell volume $(\mathrm{PCV} \%)$ of buffalo calves at consequent age intervals 


\section{5- Rectal temperature and clinical observations}

No significant differences of rectal temperature (RT) was found between control and supplemented groups. The interactions between treatment and both time and sex of calf were significant $(\mathrm{P}<0.05)$. So that, the highest variation of RT between control and supplemented groups was observed in $1^{\text {st }}$ week of age $\left(39.3^{\circ} \mathrm{C} v s .38 .4^{\circ} \mathrm{C}\right.$; Fig. 9). Also, the highest value of RT was in female of control (Fig. 10). It was observed three cases of diarrhea and one case of white muscle disease (WMD) in control group, whereas the supplemented group had not any cases. The WMD case died and it was replaced.

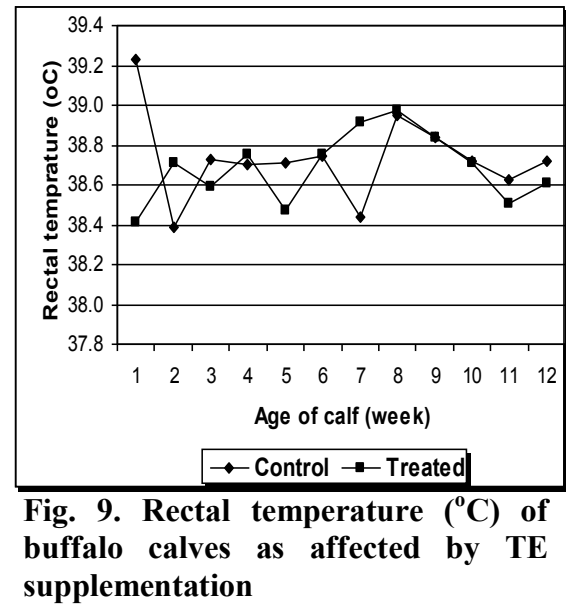

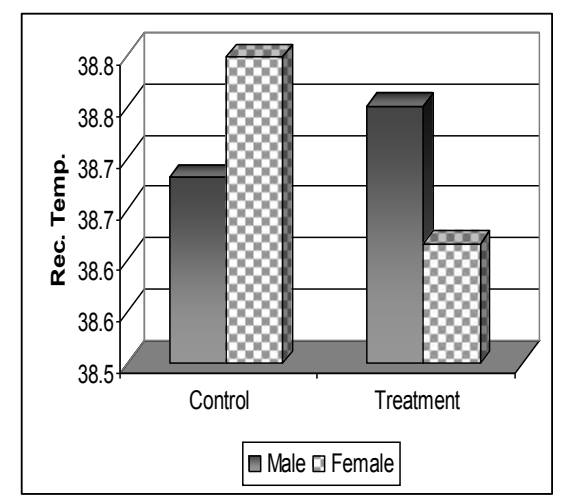

Fig. 10. Rectal temperature $\left({ }^{0} \mathrm{C}\right)$ of buffalo calves as affected by $\mathrm{TE}$ supplementation and sex of calf

\section{4- Serum trace elements}

Copper levels in blood serum (Table 5) increased significantly $(\mathrm{P}<0.05)$ from 79.9 in $\mathrm{C}$ to $88.8 \mu \mathrm{g} / \mathrm{dl}$ in TE group, but were not affected by the advancement of age. A similar trend was found by Hemingway et al. (1997). Serum Zn concentration was not altered but both of $\mathrm{Mn}$ and Fe tended to decrease $(\mathrm{P}>0.05)$ in TE group compared with untreated group. Effect of age was not evident on serum trace minerals except the lower level $(\mathrm{P}<0.05)$ of $\mathrm{Zn}$ at 4 weeks of age. From the above results it appears that $\mathrm{TE}$ concentrations in serum are not sensitive enough to supplementation with TE especially when the level of supplementation is physiologic. Similar results were reported by Salyer (2000) who found that plasma $\mathrm{Zn}$ concentration of growing heifers was not affected $(\mathrm{P}>0.05)$ when they were supplemented with $75 \mathrm{mg} \mathrm{Zn/kg} \mathrm{DM}$ as $\mathrm{ZnSO}_{4}$ or $\mathrm{Zn}$ polysaccharide. Underwood and Suttle, (1999) reported that plasma $\mathrm{Zn}$ concentration is not a reliable indicator of $\mathrm{Zn}$ status unless animals are severely deficient in $\mathrm{Zn}$. As well as, Mn in blood plasma did not respond to supplementary Mn up to $120 \mathrm{ppm}$ (Legleiter et al., 2005). Sikka et al. (2002) found that buffalo calves supplemented with mineral mixture tended to show lower concentrations of $\mathrm{Zn}$ and $\mathrm{Cu}$ in blood plasma. 
Table 5. Blood serum trace elements of buffalo calves as affected by TE supplementation and age of calf

\begin{tabular}{lccccc}
\hline \multirow{2}{*}{ Main effects } & \multicolumn{4}{c}{ Serum trace elements $(\boldsymbol{\mu g} / \mathbf{1 0 0 m})$} \\
\cline { 2 - 6 } & $\mathbf{C u}$ & $\mathbf{Z n}$ & $\mathbf{M n}$ & $\mathbf{F e}$ \\
\hline Control & 79.9 & 87.6 & 171.7 & 331.7 \\
Treatment & $88.8^{*}$ & 89.2 & 160.8 & 299.4 \\
SE & 3.01 & 3.8 & 14.1 & 13.9 \\
Age, week: & $\mathbf{2}$ & 87.1 & $101.2^{\mathrm{a}}$ & 177.3 & 309.0 \\
& $\mathbf{4}$ & 88.8 & $74.7^{\mathrm{b}}$ & 177.7 & 343.6 \\
& $\mathbf{6}$ & 84.8 & $93.1^{\mathrm{a}}$ & 152.9 & 321.3 \\
& $\mathbf{1 0}$ & 81.3 & $88.2^{\mathrm{ab}}$ & 151.3 & 303.0 \\
& $\mathbf{1 4}$ & 79.7 & $84.7^{\mathrm{ab}}$ & 171.9 & 301.1 \\
SE & 4.7 & 6.1 & 22.3 & 21.9 \\
\hline
\end{tabular}

* The difference between control and treated cows was significant at $\mathrm{P}<0.05$

${ }^{\mathrm{a}, \mathrm{b}}$ Means with differing superscripts within column are significantly different at $\mathrm{P}<0.05$

\section{5- Tissue trace elements}

Trace element concentrations in different tissues are given in Table (6). Copper in liver was increased significantly $(\mathrm{P}<0.1)$ from 6.37 in $\mathrm{C}$ to $10.30 \mu \mathrm{g} / \mathrm{g}$ fresh tissue in TE group. Also, $\mathrm{Cu}$ concentration in eye muscle and heart was higher in TE than $\mathrm{C}$ group, but without significant differences between them; whereas $\mathrm{Cu}$ concentration in lung and spleen was little changed. Engle and Spears $(2000 \mathrm{a}, \mathrm{b})$ found that $\mathrm{Cu}$ supplementation to growing beef steers increased $\mathrm{Cu}$ in the liver, whereas $\mathrm{Cu}$ in eye muscle was not altered. Also, Olson et al. (1999) found that supplementation of cows from calving to breeding with $\mathrm{Cu}, \mathrm{Co}, \mathrm{Mn}$ and $\mathrm{Zn}$ increased $\mathrm{Cu}$ in the liver.

Table 6. Tissue trace element concentrations $(\mu \mathrm{g} / \mathrm{g})$ of buffalo calves affected by TE supplementation

\begin{tabular}{|c|c|c|c|c|c|}
\hline \multirow{2}{*}{\multicolumn{2}{|c|}{ Tissue }} & \multicolumn{4}{|c|}{ Tissue trace elements $(\mu \mathrm{g} / \mathrm{g})$} \\
\hline & & $\mathbf{C u}$ & $\mathrm{Zn}$ & Mn & $\mathrm{Fe}$ \\
\hline \multirow[t]{2}{*}{ Eye M.: } & $\mathbf{C}$ & $0.65 \pm 0.54$ & $14.7 \pm 0.5$ & $1.4 \pm 1.2$ & $12.3 \pm 1.2$ \\
\hline & TE & $1.23 \pm 0.54$ & $17.2 \pm 6.4$ & $1.7 \pm 1.2$ & $16.1 \pm 1.2$ \\
\hline \multirow[t]{2}{*}{ Heart: } & $\mathbf{C}$ & $1.13 \pm 0.95$ & $13.7 \pm 0.55$ & $1.4 \pm 0.55$ & $29.3 \pm 1.04$ \\
\hline & TE & $2.20 \pm 0.95$ & $14.1 \pm 0.86$ & $4.1 \pm 1.5$ & $31.6 \pm 3.55$ \\
\hline \multirow[t]{2}{*}{ Kidney: } & $\mathrm{C}$ & $0.19 \pm 0.005$ & $12.7 \pm 0.7$ & 2.0 & $25.4 \pm 1.5$ \\
\hline & TE & $0.17 \pm 0.003$ & $15.1 \pm 1.9$ & 3.8 & $28.5 \pm 4.2$ \\
\hline \multirow[t]{2}{*}{ Liver: } & $\mathbf{C}$ & $6.37 \pm 0.29$ & $18.2 \pm 2.3$ & $3.3 \pm 1.3$ & $43.5 \pm 13.8$ \\
\hline & TE & $10.3 \pm 1.54^{*}$ & $17.3 \pm 0.7$ & $5.8 \pm 0.3$ & $51.9 \pm 8.1$ \\
\hline \multirow[t]{2}{*}{ Lung: } & $\mathbf{C}$ & 0.10 & $13.2 \pm 0.1$ & Trace & $36.8 \pm 1.7$ \\
\hline & TE & 0.13 & $13.9 \pm 0.7$ & Trace & $45.8 \pm 1.2^{* *}$ \\
\hline \multirow[t]{2}{*}{ Spleen: } & $\mathbf{C}$ & $0.40 \pm 0.3$ & $14.4 \pm 0.45$ & $3.9 \pm 3.8$ & $75.2 \pm 8.8$ \\
\hline & TE & $0.43 \pm 0.3$ & $16.0 \pm 0.45^{*}$ & $2.9 \pm 0.8$ & $71.2 \pm 4.6$ \\
\hline
\end{tabular}


Zinc content in spleen tended to be higher $(\mathrm{P}<0.1)$ in $\mathrm{TE}$ than $\mathrm{C}$ group $(16.0$ vs. $14.4 \mu \mathrm{g} / \mathrm{g})$. Whereas, $\mathrm{Zn}$ contents in other tissues were not affected by TE supplementation. The levels of $\mathrm{Mn}$ in liver and heart were higher $(\mathrm{P}>0.05)$ in TE than $\mathrm{C}$ group but in other tissues there were no differences between groups. These results agree with Olson et al. (1999) who found no effect of TE supplementation on Zn and $\mathrm{Mn}$ in the liver. Also, Legleiter et al. (2005) found that Mn levels up to $120 \mathrm{ppm}$ did not influence $\mathrm{Mn}$ in liver. On the other side, Jenkins and Hidiroglou, (1991) found that calves fed milk replacer based on skim milk powder that contained either 40 or $200 \mathrm{ppm}$ of $\mathrm{Zn}$ resulted in 10.4 and $25.0 \mu \mathrm{mol} / \mathrm{g}$ of DM of hepatic $\mathrm{Zn}$, respectively.

Iron level in lung was significantly higher $(\mathrm{P}<0.05)$ in $\mathrm{TE}$ than $\mathrm{C}$ group $(45.8$ vs. $36.8 \mu \mathrm{g} / \mathrm{g})$. While, Fe contents in eye muscle, heart, kidney and liver showed non significant increases in TE group. Bremner and Dalgarno, (1973) found that Fe supplement up to $100 \mathrm{ppm}$ increased non-significantly Fe in liver, kidney, spleen and significantly in heart and muscle. Similar results were found by Miltenburg, et al. (1991) when they supplemented $100 \mathrm{ppm}$ of Fe in milk replacer to newborn Frisian calves. They noted that muscle and liver Fe concentrations did not differ significantly in supplemented group. On the other side, Roy et al. (1964) found that Fe supplementation to suckling calves increased $(\mathrm{P}<0.01)$ liver $\mathrm{Fe}$ concentration but did not affect significantly Fe in pectoral muscle.

\section{6- Hair trace elements}

Least square means of $\mathrm{Cu}, \mathrm{Zn}, \mathrm{Mn}$ and $\mathrm{Fe}$ concentrations of calf's hair are presented in Table (7). No significant differences were found between treated and control groups for all elements. The level of $\mathrm{Cu}$ in the TE group was higher $(\mathrm{P}<0.1)$ in $6^{\text {th }}$ week of age than $\mathrm{C}$ group (Fig. 11). On the other hand, Mn concentration in C group declined $(\mathrm{P}<0.05)$ at $15^{\text {th }}$ week of age but increased in treated group (Fig. 12). The concentration of $\mathrm{Cu}$ and $\mathrm{Zn}$ of calf's hair was greater $(\mathrm{P}<0.05 ; \mathrm{P}<0.1$, respectively) at 6 week of age than at $15 \mathrm{wk}$, likewise with Mn contents but without significant differences. However, Fe concentration was higher $(\mathrm{P}<0.05)$ at weaning (15 wk of age). There is no or a few studies are available concerning hair mineral contents as affected by TE supplementation to ruminants or livestock.

Table 7. Hair trace element concentrations $(\mu \mathrm{g} / \mathrm{g})$ of buffalo calves affected by TE supplementation

\begin{tabular}{|c|c|c|c|c|}
\hline \multirow{2}{*}{ Main effects } & \multicolumn{4}{|c|}{ Hair trace elements $(\mu \mathrm{g} / \mathrm{g})$} \\
\hline & $\mathbf{C u}$ & $\mathbf{Z n}$ & Mn & $\mathrm{Fe}$ \\
\hline Control & 5.9 & 128.9 & 12.3 & 71.4 \\
\hline Treatment & 6.6 & 119.1 & 10.9 & 64.6 \\
\hline SE & 0.4 & 7.7 & 3.4 & 3.2 \\
\hline Age, week: 6 & $6.9^{*}$ & 129.8 & 10.9 & 63.2 \\
\hline 15 & 5.6 & 118.2 & 12.3 & $72.9^{*}$ \\
\hline SE & 0.4 & 7.7 & 3.4 & 3.1 \\
\hline
\end{tabular}

$* \mathrm{P}<0.05$ 


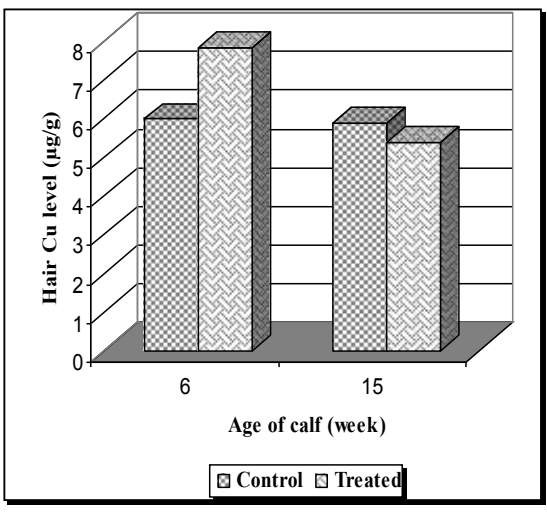

Fig. 11. Hair $\mathrm{Cu}$ concentration of buffalo calves as affected by $\mathrm{TE}$ supplementation

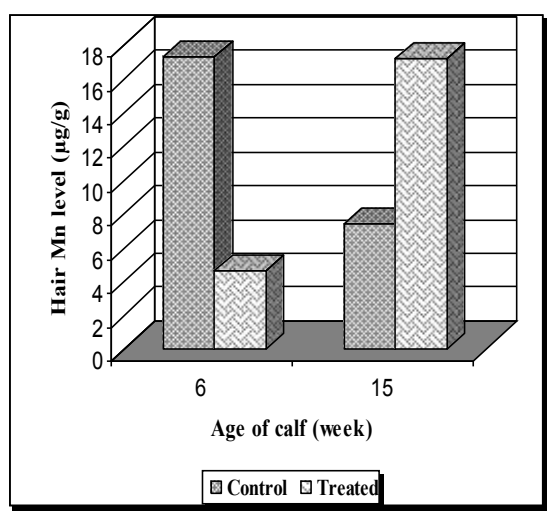

Fig. 12. Hair Mn concentration of buffalo calves as affected by $\mathrm{TE}$ supplementation

\section{CONCLUSION}

It can be concluded that the trace elements supplementation to suckling calves did not affect growth rate, blood hematology and metabolites, as well as manganese and iron concentrations in serum, tissues or hair. However, the trace elements supplementation improved $\mathrm{Cu}$ and $\mathrm{Zn}$ status; and the immune status of calves against diarrhea and white muscle disease.

\section{REFRENCES}

A.O.A.C., 1990. Association of Official Analytical Chemists. Official Methods of Analysis. $13^{\text {th }}$ ed., Washington, D.C. USA.

Abd El-Hady, M.A.A., R.W. Raghib and G. H. Metry, 2005. Influence of selenium and vitamin $\mathrm{E}$ administration of late pregnancy buffalo cows on maternal transfer of selenium and immunoglobulins to their calves. J. Agric. Sci. Mansoura Univ., 30(12): 7413-7424.

Abd El-Hady, M.A.A., K.T. Osman, Eid, N. Lila, and S.A. El-Ayouty, 2006. Influence of organic and inorganic forms of zinc supplemented to late pregnancy buffalo cows on zinc status, growth and passive immunity transfer of newborn calves. Society of Physiological Sci. and their Applications, In press.

Adams, R., F.B. Garry, B.M. Aldridge, M.D. Holland and G. Odde, 1993. Physiologic differences between single and twinborn beef calves in the first two days of life. Cornell Vet. 83:13 (CF. Kume and Tanabe 1996).

Arrayet, J.L., A.M. Oberbauer, T.R. Famula, I. Garnett, J.W. Oltjen, I. Imhoof, M.F.Jr. Kehrli and T.W. Graham, 2002. Growth of Holstein calves from birth to 90 days: The influence of dietary zinc and BLAD status. J. Anim. Sci. 80: $545-$ 552. 
Bremner, I. and A.C. Dalgarno, 1973. Iron metabolism in the veal calf. 2- Iron requirements and the effect of copper supplementation. Br. J. Nutr. 30: 61-76.

Duncan, D.B., 1955. Multiple range and multiple F-test. Biometrics, 11:1-42.

El-Ayouty, S.A., G.H. Metri, A.A. Gabr and M.A.A. Abd El-Hady, 1996. Selenium nutrition of the sukling buffalo calves. Egyptian J. Anim. Prod., 33, Suppl. Issue, Nov. (1996): 123-136.

El-Ayouty, S.A., G.H. Metry, A.A. Gabr, M.A.A. Abd El-Hady and R.M. Khattab, 2003. Studies on selenium status of suckling buffalo calves: I- Effect of selenium and/or vitamin $\mathrm{E}$ administration on growth performance, plasma selenium concentrations, enzyme activities and the prevention of white muscle disease. Egyptian J. Anim. Prod. 40: 1-13.

Engle, T. E. and J. W. Spears, 2000a. Dietary copper effects on lipid metabolism, performance, and ruminal fermentation in finishing steers. J. Anim. Sci. 78:24522458.

Engle, T.E. and J.W. Spears, 2000b. Effects of dietary copper concentration and source on performance and copper status of growing and finishing steers. J. Anim. Sci. 78:2446-2451.

Gunter, S. A., P.A. Beck and J.K. Phillips, 2003. Effects of supplementary selenium source on the performance and blood measurements in beef cows and their calves. J. Anim. Sci., 81: 856-864.

Gustafson, G.M., 2000. Partitioning of nutrient and trace elements in feed among milk, faeces and urine by lactating dairy cows. Acta Agric. Scan., Sect. A, Animal Sci. 50: 111-120.

Hatfield, P.G., C.K Swenson, R.W. Kott, R.P. Ansotegui, N.J. Roth and B.L. Robinson ,2001. Zinc and copper status in ewes supplemented with sulphate- and amino acid-complexed forms of zinc and copper. J. Anim. Sci. 79: 261-266.

Hemingway, R.G., J.J. Parkins and N.S. Ritchie, 1997. Sustained-release Boluses to Supply Trace Elements and Vitamins to Calves. The Veterinary J. 153: 221-224.

Hermansen, J.E., J.H. Badsberg, T. Kristensen and V. Gundersen, 2005. Major and trace elements in organically or conventionally produced milk. J. Dairy Res. 72: $1-7$.

Jenkins, K.J. and M. Hidiroglou, 1991. Tolerance of the preruminant calf for excess manganese or zinc in milk replacer. J. Dairy Sci. 74: 1047-1053.

Kessler, J., I. Morel, F.A. Dufey, A. Gutzwiller, A. Stern and H. Geyes, 2003. Effect of organic zinc sources on performance, zinc status, and carcass, meat, and claw quality in fattening bulls. Livest. Prod. Sci. 81:161-171.

Kume, S. and S. Tanabe, 1994. Effect of twinning and supplementing iron saturated lactoferrin on iron status of newborn calves. J. Dairy Sci. 77: 3118-3123.

Kume, S and S. Tanabe, 1996. Effect of supplemental lactoferrin with ferrous iron on iron status of newborn calves. J. Dairy Sci. 79: 459-464.

Legleiter, L.R., J.W. Spears and K.E. Lloyd, 2005. Influence of dietary manganese on performance, lipid metabolism and carcass composition of growing and finishing steers. J.Anim.Sci.83: 2434-2439.

Masters, D.G. and R.J. Moir, 1983. Effect of zinc deficiency on the pregnant ewe and devloping foetus. Br.J.Nutr. 49: 365-372.

Mee, J.F., P.A. Rogers and K.J. O'Farrell, 1995. Effect of feeding a vitamin-mineral supplement before calving on the calving performance of a trace element deficient herd. Vet. Rec. 137:508-512. 
Michel, M.C., 1976. Role des profils metaboliques dans la recherche des causes des maladies de production lépèce bovine. Proc. 9e Congr Int. Sur les Maladies du Bétail Paris pp 571-582.

Miltenburg, G.A.J., T. Wensing, J.P.M. Van Vliet, G. Schuijt, J. Van de Broek and H.J. Breukink, 1991. Blood hemoglobin, plasma iron and tissue iron in dams in late gestation at calving and in veal calves at delivery and later. J. Dairy Sci. 74: 3086-3094.

Muehlenbein, E.L, D.R. Brink, G.H. Deutscher, M.Pb. Carlson and A.B. Johnson, 2001. Effects of inorganic and organic copper supplemented to first-calf cows on cow reproduction and calf health and performance. J. Anim. Sci. 79: 1650-1659.

NRC., 2001. Nutrient Requirements of Dairy Cattle. $7^{\text {th }}$ revised edition. National Academy Press, Washington, D.C.

Olson, P.A., D.R. Brink, D.T Hickok, M.P. Carlson, N.R. Schneider, G.H. Deutscher, D.C. Adams, D.J. Calburn and A.B. Johnson, 1999. Effects of supplementation of organic and inorganic combinations of copper, cobalt, manganese and zinc above nutrient requirements on post-parturition two year old cows. J. Anim. Sci. 77: 522-532.

Reitman, A. and S. Frankle, 1957. A colorimetric method for the determination of serum glutamic-oxaloacetic and glutamic-pyrovic transaminase. Amer. J. Clin. Path., 28: 56.

Riordan, J.F. and B.L. Valle, 1976. Structure and function of zinc metalloenzymes. In: A. S. Prasad (Ed.). Trace elements in human health and disease. pp 227-251. Vol. 1. Academic Press, New York, NY.

Roy, J.H.B., Helen, J. Gaston, K.W.G. Shillam, S.Y. Thompson and I.J.F. Stobo, 1964. The effect of anemia and of iron chlortetracycline supplementation on the performance of calves given large quantities of whole milk. Brit. J. Nutr. 18: 467502.

Salyer, G.B., 2000. The effects of copper and zinc source on performance, morbidity and immune response of stressed heifers. $\mathrm{PhD}$ thesis, Texas Tech. University.

SAS, 1996. SAS User's Guide, SAS (Statistical Analysis System) Institute, Cary, NC.

Sikka, P., D. Lall, U. Arora and R.K. Sethi, 2002. Growth and passive immunity in response to micronutrient supplementation in new-born calves of Murrah buffaloes given fat soluble vitamins during late pregnancy. Livestock Prod. Sci. 75: 301-311.

Struharikova, J., P. Slivka, L. Slanina, D. Sotak, A. Elbertova and P. Polahar, 1989. Peroral administration of zinc sulfate to pregnant cows and its effect on selected metabolic indicators in the dam-calf lineage. Vet. Med. (Praha) 34(4): 193-202.

Suttle, N.F., A.C. Field, T.B. Nicolson, A.O. Mathieson, N. Prescott and W.S. Johnson, 1980. Some problems in assessing the physiological and economic significance of hypocupraemia in beef suckler herds. Vet. Rec. 106: 302-304.

Swinkels, J.W.G.M., E.T. Kornegay, W. Zhou, M.D. Lindemann, K.E. Webb and M.W.A. Verstegen, 1996. Effectiveness of a zinc amino acid chelate and zinc sulphate in restoring serum and soft tissue zinc concentrations when fed to zincdepleted pigs. J. Anim. Sci. 74: 2420-2430.

Underwood, E.J. and N.F. Suttle, 1999. The Mineral Nutrition of Livestock. CABI Publishing. New York. 
Wasiak, W., W. Ciszewska and A. Ciszewski, 1996. Hair analysis. Part 1: Differential pulse anodic stripping voltammetric determination of lead, cadmium, zinc and copper in human hair samples of persons in permanent contact with a polluted workplace environment. Analytica Chimica Acta 335: 201-207.

Wright, C.L. and J.W. Spears, 2004. Effect of Zinc Source and Dietary Level on Zinc Metabolism in Holstein Calves. J. Dairy Sci. 87: 1085-1091. 


\title{
تأثير إضافة العناصر المعدنية النادرة لعجول الجاموس الرضيعة
}

\author{
ماجد عبدالهادى عبدالعزيز عبدالهادى'، السيد أحمد العيوطى'، أحمد السيد ختيزى' \\ 1 - معهُ بحوث الإتتاج الحيوانس، مركز البحوث النزاعية، الدقى، الجيزة، مصر، r - قسم الانتاج الحيوانس،

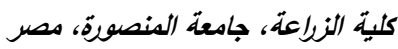

أجريت هذه الدراسة لنقييم تأثير إضافة مخلوط أملاح معدنية للعجول الجاموسى الرضيعة فى اللبن

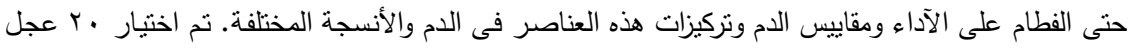

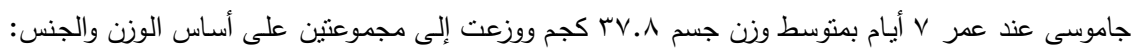

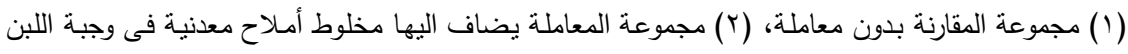

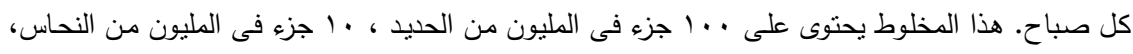

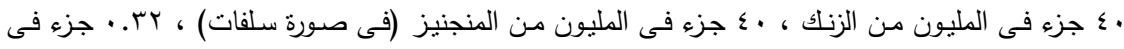

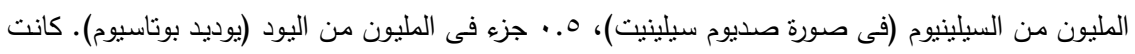

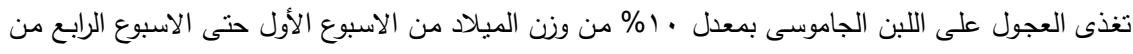

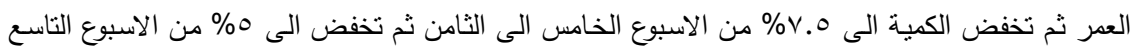
وحتى الفطام على 10 أسبوع. وقد كان بادئ العجول ودريس البرسيم متوفر أمام الحيوانات من الاسبوع الثانى الثانى

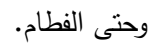

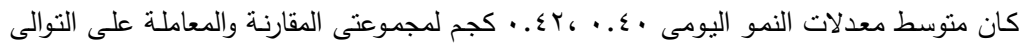

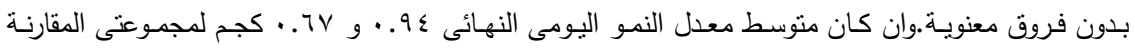

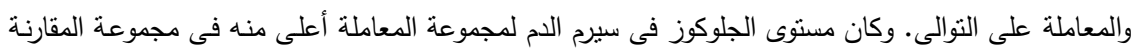

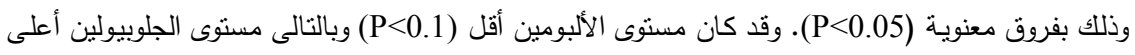

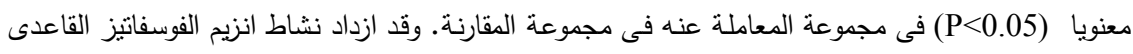

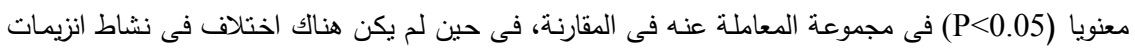

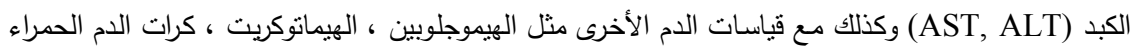

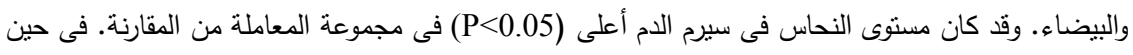

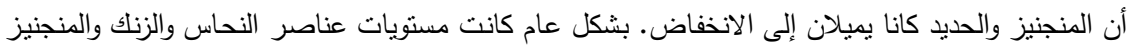

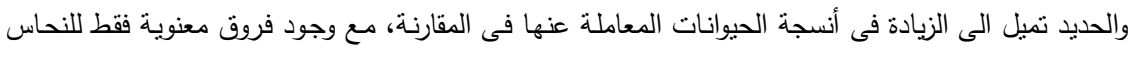

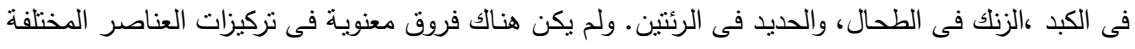
فى الثعر بين المجاميع.

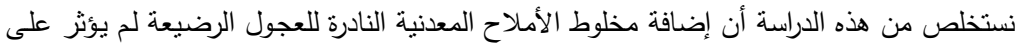

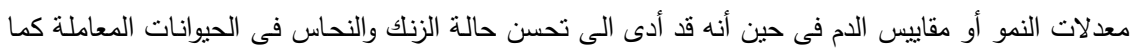

